\section{PLACE-NAMES OF SCOTLAND.}

Place-names of Scotland. By James B. Johnston, B.D. Second edition. Pp. cxi+308. (Edinburgh : David Douglas 1903) Price 6s. net.

THE author of this work aims to do for Scotland what Dr. Joyce in his "Irish Names and Places " has already done for Ireland. It is a laudable attempt and one that is full of interest. Not only do we get here an alphabetical list of a large number of the place-names of Scotland, with explanations of their origin, but introductory chapters dealing at some length with the different sources from which have sprung the characteristic names of North Britain. Thus Mr. Johnston gives an account of the Celtic, Norse, English, Roman, Norman, modern, and ecclesiastical names, aiming to make his treatment of the subject no mere dilettante trifling, but a work based on historic evidence. He has in many cases ransacked old books and documents to get the older forms of the words as a guide to their original meaning, and this is really the most valuable part of the task he has undertaken. Had he consistently followed out his own principles enunciated in the introduction, his work would have been of a much higher order and free from the defects which too obviously encumber it. As it is, many of his derivations are quite as fantastic as the " mouth-esk-burgh" for Musselburgh, which by the laws of phonetics he solemnly rejects.

The real reason for the inequalities which even a second edition of the book, after twelve years' interval, has failed to remove is the author's inadequate acquaintance with the Gaelic language. As he admits himself, the Celtic names constitute the largest and most complicated portion of his task.

" The Celt's warm, emotional heart loved to seek out the poetry and colour in the world around, and many of his place-names show that 'stern nature was his daily companion, and friend.' Indeed, the majority of Celtic names give either the simplest possible description of the site named, or describe some prominent feature, or else the colouring or appearance of it as it strikes the eye."

In view of this, it is obvious that a thorough knowledge of the original language spoken in the country, as well as of the topography, is essential to the writer who would adequately discuss the meaning of the place-names; without it there must necessarily be much juggling with words.

If Mr. Johnston really knew the Celtic laws of aspiration and eclipsis, he would never say that the Gael loves to speak of the " Shawms of David," nor would he, when deriving Nairn from G. an earrann, find it necessary to suppose that Auchenairn must be Auchencairn through loss of c. Clachnaharry is clach na h'aire. "stone of watching," and yet he cannot think what Altnaharra is unless allt-na-charraigh, " stream with the pillar or rock," or from marbhaidh, " of the slaughter."

Allt, which is a streamlet passing through a ravine, NO. I 8 I3, vOL. 70] he interprets sometimes as a glen or river. Kil, so common in the place-names of Scotland, becomes at one time cill, church, at another caol, narrow, again cul, back, and yet again coille, a wood, in the most arbitrary fashion. Auchter suffers in the same way, being uachdar or achadh just as suits his fancy. Take the three words ending in ellan. Killellan, we are told, is " church of St. Fillan," Inellan, en eilean, "bird-island," Balmaclellan, "village of John Maclellan." On the same principle Balmaghie becomes in this book "village of Macghie," whereas it more probably means "wind-swept town," like Tonderghie, not far away from it, which means " back to the wind." Another form of the word, Balmuchie, ludicrously appears as " the house or farm of swine." Banavie, he says, is probably not the "Vicus Bannavern" of St. Patrick's birth; why probably in a matter so entirely certain by every form of evidence?

Mr. Johnston says " every 'ness' is Norse, this being the Icel. nes, Dan. Naes, a nose," and he admits that it may be traced in names like Stromness and Deerness. Yet when he comes to Alness he has recourse to the extraordinary derivation G. ath'n-innis, " ford of the island" (the Black Isle). It would indeed take as violent a stretch of imagination to suppose that the Cromarty Firth was fordable at Alness as to imagine that Rogart means " red enclosure," "from the Old Red Sandstone here." As a matter of fact there is no Old Red Sandstone there, only granite. But these derivations are no less ingenious and far-fetched than that for Belleville, near Kingussie, which in a footnote Mr. Johnston says is in G. bail-a-bhile (sic), "village at the brae-top." Who with any claim to Celtic literary knowledge does not know that Belleville is the name which James Macpherson of Ossianic fame gave to the house which he built in the eighteenth century, thus superseding the former name of the place, which was called Raitts? No Highlander would translate allt grad as " ugly burn," or write achadh tuas for " field above" as the derivation of Auchtose. Ptolemy in his ancient map did not apply the name Varar, as here alleged, to the Moray Firth, but to the estuary of the Farrar, now the Beauiy.

Many of the most beautiful ancient names in the country, such as the names of farms, little hills, lochs and rivulets, as well as hundreds of names beginning with prefixes such as tigh, allt'tobar, Ceann, Cnoc, \&c., are left wholly untouched. One wonders on what principle the author selects some of the names he inserts and omits others. There are not more than about 500 names worthy of note in his own county of Stirling, he says. Why! there are almost as many in many a parish.

Yet for all its defects Mr. Johnston has written a book which is a good foundation for a better, and will have a fascination for a great many people, and it is quite true, as he says, that the historian, the philologist, the antiquarian, and the anthropologist will, each and all, find in it sidelights both helpful and interesting. 